\title{
Gliptin Therapies for Inhibiting Dipeptidyl Peptidase-4 in Type 2 Diabetes
}

\author{
Brian D Green, ${ }^{1}$ Clifford J Bailey ${ }^{2}$ and Peter R Flatt ${ }^{3}$ \\ 1. Senior Lecturer in Molecular Nutrition, and Deputy Director of Research, School of Biological Sciences, Queens University Belfast; \\ 2. Professor of Clinical Science, and Head of Diabetes, School of Life and Health Sciences, Aston University, Birmingham; \\ 3. Professor of Biomedical Sciences, and Head, Diabetes Research Group, School of Biomedical Sciences, University of Ulster
}

\begin{abstract}
Discovery of the incretin hormones glucagon-like peptide-1 (GLP-1) and glucose-dependent insulinotropic polypeptide (GIP) has led to the clinical development of incretin-based therapies for type 2 diabetes. Incretins are intestinal peptide hormones that stimulate post-prandial insulin secretion and improve glycaemic control. Gliptins are drugs that inhibit a ubiquitous enzyme, dipeptidyl peptidase-4 (DPP-4), preventing the physiological breakdown of incretins and thereby enhancing endogenous incretin action. Three 'gliptins' have recently been introduced into clinical practice: sitagliptin, vildagliptin and saxagliptin. This review provides an overview of these new antidiabetic agents and comments on some exciting future prospects for incretins and agents that enhance incretin action.
\end{abstract}

\section{Keywords}

Diabetes, incretin, gliptin, antidiabetic drugs, glucagon-like peptide-1 (GLP-1), glucose-dependent insulinotropic polypeptide (GIP), dipeptidyl peptidase-4 (DPP-4)

Disclosure: Brian D Green has no conflicts of interest to declare. Clifford J Bailey has undertaken ad-hoc consultancy in the past for pharmaceutical companies including Merck Sharp \& Dohme and Takeda. Peter R Flatt has undertaken research sponsored by pharmaceutical companies, but not related to this manuscript. Received: 2 December 2009 Accepted: 8 June 2010 Citation: European Endocrinology, 2010;6(2):19-25 DOI:10.17925/EE.2010.06.02.19 Correspondence: Brian D Green, School of Biological Sciences, Queens University Belfast, Belfast, Northern Ireland, BT9 5AG, UK. E: b.green@qub.ac.uk

\section{Intestinal Hormones and Glucose Regulation}

The importance of the intestine in regulating post-prandial glucose levels unfolded over the latter half of the 20th century. Observations in the early 20th century demonstrated that intestinal extracts could alleviate diabetes, but these studies were overlooked. ${ }^{1{ }^{2}}$ It was not until the 1960s that the 'enteroinsular axis' and the incretin effect were defined. The enteroinsular axis is a network of neural and endocrine signals between the intestine and the pancreas that promote insulin release in response to feeding. ${ }^{3}$ Incretins are intestinal endocrine hormones and are important components of the enteroinsular axis. ${ }^{3}$ Thus far, two incretin hormones that potently stimulate insulin secretion at physiological concentrations have been identified: glucagon-like peptide-1 (GLP-1) and glucose-dependent insulinotropic polypeptide (GIP).

\section{The Incretin Hormones - Discovery and Physiological Actions}

GLP-1 was discovered in complementary DNA (CDNA) derived from the anglerfish when molecular biology techniques were employed to investigate the proglucagon gene. ${ }^{4}$ Subsequent work revealed the mammalian sequences of GLP-1 and identified GLP-1(7-36) amide as the major bioactive peptide, characterised by a potent dose-dependent insulinotropic action. ${ }^{5,6} \mathrm{GIP}$ was identified much earlier than GLP-1 in an impure porcine enterogastrone extract.? Initial effects on the stomach gave rise to the original name 'gastric inhibitory polypeptide', which was later changed to reflect its potent insulin secretory action on pancreatic beta-cells.-11 GLP-1 and GIP are released post-prandially from intestinal L- and K-cells, respectively, and they are effective modulators of glucose-dependent insulin secretion. ${ }^{6.12}$ This glucose-dependent character has been a key feature in the clinical exploitation of incretins because it limits the risk of hypoglycaemia. In vitro studies have shown that GLP-1 and GIP can upregulate pro-insulin gene transcription and enhance the growth, differentiation, proliferation and survival of pancreatic beta-cells. ${ }^{13-15}$ Furthermore, GLP-1 and GIP appear to act as a beta-cell mitogenic and anti-apoptotic factor. ${ }^{16,17}$ The hormones have a range of extrapancreatic effects (see Figure 1), which are reviewed elsewhere. ${ }^{6}$ Regulatory actions of incretins involve effects on glucose and energy metabolism as well as having actions on the liver, skeletal muscle and adipose tissues. ${ }^{5,6,18-20}$ As a consequence of the early work characterising biological actions, the incretin hormones gradually gained a reputation as novel therapeutic agents for the treatment of diabetes and related metabolic disorders. ${ }^{6}$

\section{Metabolism of the Incretins by Dipeptidyl Peptidase-4}

Dipeptidyl peptidase-4 (DPP-4) was one of the earliest identified prolyl peptidases. Its wide range of important physiological substrates has helped make it one of the most intensively studied enzymes of this family. ${ }^{21}$ The activity of DPP-4 is relatively selective because only peptide bonds penultimate to the $\mathrm{N}$-terminus that follow a proline or alanine (and in some cases a serine) are cleaved. ${ }^{21}$

DPP-4 is ubiquitous, existing as a soluble form in circulating blood and also as a membrane-anchored form present in the endothelia and epithelia of tissues such as bone marrow, kidney, intestine, pancreas, liver, lymphocytes, placenta, uterus, prostate and skin. ${ }^{21}$ 


\section{Figure 1: Physiological Actions of the Incretin Hormones Glucagon-like Peptide-1 and Glucose-dependent Insulinotropic Polypeptide}

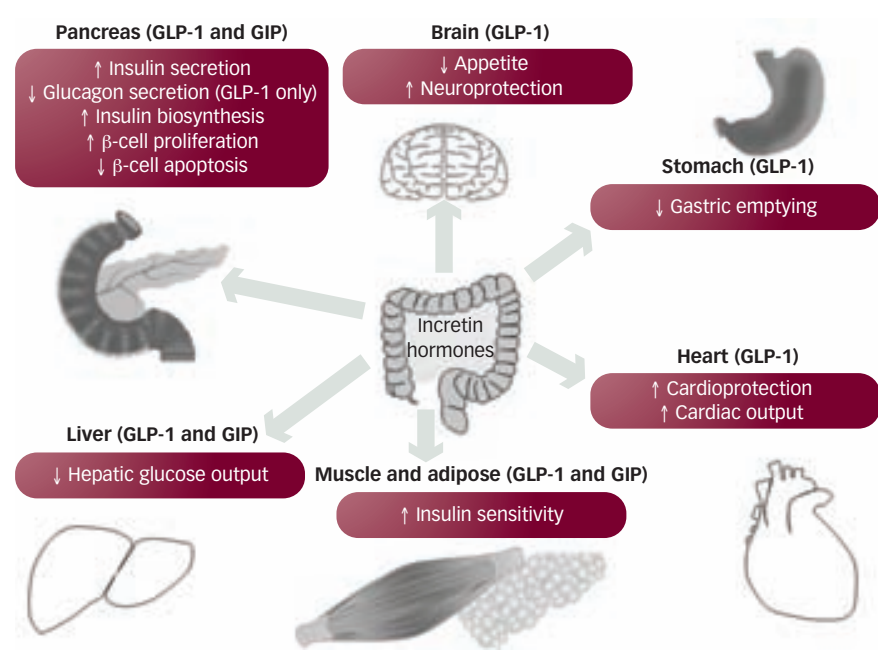

Physiological effects of the incretin hormones that exert diverse biological actions on a number of human target organs, such as the pancreas, liver, stomach, muscle, adipose tissue, heart and brain.

$G I P=$ glucose-dependent insulinotropic polypeptide; GLP-1 = glucagon-like peptide-1.

The expression and activity of DPP-4 in certain tissues and blood plasma can vary significantly in response to disease, injury or inflammation (reviewed elsewhere). ${ }^{21,22}$ It is therefore not surprising that the physiological role of DPP-4 is wide-ranging. It is capable of interacting with large proteins such as collagen, fibronectin and adenosine deaminaseas as well as many peptide substrates (see review). ${ }^{23}$ Among the most commonly recognised substrates of DPP4 are several chemokines affecting the immune system, several neuropeptides with wide-ranging actions and the counter-regulatory hormone glucagon. ${ }^{23}$

Degradation of GLP-1 and GIP by DPP-4 in vitro was first demonstrated by Mentlein and co-workers. ${ }^{24}$ They observed the enzymatic removal of N-terminal dipeptides His7-Ala8 and Tyr ${ }^{1}$-Ala 2 from GLP-1 and GIP, respectively, when incubated with DPP-4 purified from the human placenta. Importantly, they went on to observe that GLP-1 and GIP were similarly degraded when incubated in human serum. ${ }^{24}$ Subsequently, it was confirmed that DPP-4-mediated metabolism of GLP-1 and GIP also occurred in vivo..$^{24,25}$ This action of DPP-4 reduces the in vivo half-life of GLP-1 and GIP to less than two minutes. ${ }^{25-27}$ Since the active forms of incretin hormones are GLP-1(7-36) amide and GIP(1-42), degradation by DPP-4 leads to inactivation with the accumulation of major degradation fragments GLP-1(9-36) amide and GIP(3-42), respectively.

The receptor binding characteristics and actions of these fragments have been elucidated. GLP-1(9-36) amide and GIP(3-42) are both non-insulinotropic peptides and it was initially suggested that these were relatively inert and inactive metabolites. ${ }^{26-28}$ The affinity of GLP-1(9-36) amide for the GLP-1 receptor is 100-fold lower than that of the parent molecule and it appears to act as a weak receptor antagonist. ${ }^{29-31}$ While GLP-1(9-36) amide does not antagonise the insulinotropic activity of physiological GLP-1(7-36) amide concentrations in vivo, there is some evidence that this metabolite possesses weak antihyperglycaemic activity through a mechanism not involving insulin secretion. ${ }^{32}$
Following truncation by DPP-4, the receptor affinity of GIP(3-42) is approximately four-fold lower than that of GIP(1-42). ${ }^{33} \mathrm{GIP}(3-42)$ has been shown to antagonise the GIP receptor in vitro. ${ }^{34,35}$ However, different results have been generated by in vivo studies. ${ }^{34-36}$ Thus, although GIP(3-42) antagonises GIP-stimulated adenosine $3^{\prime} 5^{\prime}$ cyclic monophosphate (CAMP) production and insulin secretion in vitro, it does not behave as an antagonist at physiological concentrations in vivo. $^{33}$ Indeed, a pharmacological dose of GIP(3-42) (25nmol $/ \mathrm{kg}$ ) administered to obese diabetic (ob/ob) mice once daily for 14 days enhanced insulin sensitivity and improved glycaemic control. ${ }^{36}$ This appears to involve extrapancreatic mechanisms aroused by compromised GIP action, leading to improved insulin sensitivity (for a review see Irwin and Flatt). ${ }^{37}$ However, during studies with GIP(3-42) or GLP-1(9-36) amide there were no effects on bodyweight, food intake, pancreatic insulin content or islet morphology. ${ }^{36}$

\section{Pre-clinical Studies 'Knocking Out' or Inhibiting Dipeptidyl Peptidase-4}

One of the first DPP-4 inhibitors employed as a biological tool to better understand DPP-4 was a tripeptide (Ileu-Pro-Ileu) called diprotin A. $^{38,39}$ Structural studies using human DPP-4 revealed that diprotin A covalently bonded to Ser630 in the catalytic site and this irreversibly blocked the enzyme active site. ${ }^{40}$

The concept of gliptins was supported by promising studies involving mice and rats lacking functional DPP-4. Such proof-of-concept studies (briefly summarised below) led to a new hypothesis: that specific inhibitors of DPP-4 could improve glucose homeostasis and thus could potentially be used to treat type 2 diabetes. Mice that lack DPP-4 activity have significantly reduced glycaemic excursions and greater levels of glucose-stimulated insulin and show extended activity of GLP-1 and GIP. ${ }^{41}$ Similarly, rats deficient in DPP-4 have improved glucose tolerance, enhanced insulin release and higher levels of active GLP-1. ${ }^{42}$ A series of other studies further underpinned this by demonstrating that a lack of DPP-4 lessened food intake, increased energy expenditure and granted animals resistance to the development of glucose intolerance, diabetes and obesity. ${ }^{43,44}$

One of the first DPP-4 inhibitors to be developed and tested in animal models of type 2 diabetes was P32/98 (isoleucine thiazolidide). Oral administration of P32/98 acutely improved glucose tolerance in Zucker fatty rats. ${ }^{45}$ Chronic treatment (12 weeks) of Zucker rats with P32/98 improved glucose tolerance and increased plasma insulin levels, but did not lead to any measurable changes in beta-cell mass or islet morphology. ${ }^{46}$ P32/98 reduced weight gain and improved hepatic and peripheral insulin sensitivity. ${ }^{46,47}$ Another inhibitor, LAF-237 (later named vildagliptin), dose-dependently controlled glycaemia in insulin-resistant rats over a three-week period. ${ }^{48}$ Another inhibitor called NVP-DPP728 improved glucose tolerance and increased the circulating levels of active GLP-1. ${ }^{49}$ The effectiveness of the inhibitor valine-pyrrolidide was demonstrated in high-fat-fed mice. Valine-pyrrolidide improved glucose tolerance and potentiated the insulin response to intra-gastric glucose. ${ }^{50}$

Early experiments exploring possible combinatorial therapies involving DPP-4 inhibitors were undertaken in diabetic mouse models. Combining vildagliptin with rosiglitazone did not provide any additional efficacy to rosiglitazone alone; however, it did appear to reduce common side effects such as weight gain and haemodilution. ${ }^{5}$ combining a DPP-4 inhibitor with an alpha-glucosidase inhibitor had an additive effect on glucose tolerance and increased active GLP-1 levels. ${ }^{52}$ 
Wider dissemination of pre-clinical studies with DPP-4 inhibitors, and particularly their adoption into clinical trials, has led to a proliferation in the number of DPP-4 inhibitor compounds under investigation. The outcomes of these trials remain to be seen. ${ }^{53-55}$

\section{Clinical Use of Gliptins}

Three gliptins have become available for clinical use in the UK: sitagliptin (Januvia, 2007), vildagliptin (Galvus, 2008) and saxagliptin (Onglyza, 2009). Their pharmacokinetic features are summarised in Table $1^{56-58}$ The dosages and administration schedules used in the treatment of diabetes produces almost total inhibition of DPP-4 activity over 24 hours, increasing the post-prandial circulating concentrations of active GLP-1 and GIP by two- to three-fold. This is associated with increased meal-stimulated or glucose-stimulated insulin secretion and reduced glucagon concentrations.

Several randomised controlled trials have affirmed the glucose-lowering efficacy of gliptins in type 2 diabetes patients (see Tables 2-4). When used as monotherapy or in combination with other antidiabetic agents, gliptins have typically reduced glycated haemoglobin $\left(\mathrm{HbA}_{1 \mathrm{C}}\right)$ by about $0.5-1 \%{ }^{59-74}$ Efficacy is often greater if the baseline $\mathrm{HbA}_{1 \mathrm{c}}$ is $>8 \%$. Several studies have shown durable efficacy up to one year. Basal glycaemia is usually decreased by about $1-1.5 \mathrm{mmol} / \mathrm{l}$, while post-prandial glucose concentrations are lowered by about $3 \mathrm{mmol} / \mathrm{I}^{59-74}$

The effects of gliptins are generally additive to those of other antidiabetic agents, provided there is adequate remaining beta-cell function. Usage has been mainly in combination with agents that improve insulin sensitivity (metformin or a thiazolidinedione). However, gliptins can also be used with a sulphonlyurea or meglitinide to further enhance the insulin response because incretins act on beta-cells via a separate cellular mechanism involving specific G-protein-coupled receptors.

Monotherapy with a gliptin carries a low risk of interprandial hypoglycaemia, although hypoglycaemia is more evident when gliptins are used in combination with other agents, notably sulphonylureas. ${ }^{75-77}$ This reflects the mode of action via incretins to potentiate nutrient-induced insulin secretion, but not to initiate insulin secretion at low glucose concentrations. Also, the glucagon-lowering effect of GLP-1 is lost at low glucose concentrations, helping to preserve an acute counter-regulatory response. ${ }^{78}$

The extent to which gliptins raise active GLP-1 concentrations does not appear to be sufficient to significantly reduce the rate of gastric emptying, hence gliptins do not tend to cause the nausea that is sometimes experienced after an injection of GLP-1 agonists. Gliptins are generally regarded as weight-neutral agents and may assist a small amount of weight loss. ${ }^{79,80}$ They may have a mild satiety effect by increasing active GLP-1 concentrations in the portal circulation and liver, where GLP-1 triggers vagal afferents, affecting satiety. Gliptins may produce modest improvements in the postprandial lipid profile. ${ }^{81}$

An exciting future prospect where gliptins could play an important role involves the potential use of pharmacological agents to boost endogenous secretion of incretin hormones. The notion of developing a combinatorial therapy that contains a GLP-1 secretagogue and a gliptin compound is a concept that is gaining momentum. Possible receptor targets on L-cells for increasing GLP-1 exocytosis include GPR119, GPR120 and TG5R. ${ }^{82,83}$

\section{Table 1: Pharmacokinetic Features of Gliptins}

\begin{tabular}{llll} 
& Sitagliptin & Vildagliptin & Saxagliptin \\
\hline Launch in UK & 2007 & 2008 & 2009 \\
\hline Dose & $100 \mathrm{mg}$ OD & $50 \mathrm{mg}$ BID & $5 \mathrm{mg}$ OD \\
\hline Bioavailability & $\sim 87 \%$ & $\sim 85 \%$ & $50-75 \%{ }^{*}$ \\
\hline $\mathrm{T}_{\max }$ & $1-4$ hours & $\sim 1.7$ hours & $2-4$ hours \\
\hline Protein bound & $\sim 32 \%$ & $\sim 9 \%$ & Negligible \\
\hline Metabolism & $\sim 20 \%$ & $\sim 70 \%$ & $\sim 75 \%$ \\
& metabolised & metabolised & metabolised \\
& (mainly liver) & (mainly renal) & (mainly liver) \\
\hline Metabolites & Very weak activity & Mostly inactive & Active \\
\hline Half-life & $\sim 12$ hours & $2-3$ hours & $2.5-3$ hours \\
\hline Elimination & $\sim 80 \%$ in urine, & $\sim 85 \%$ in urine, & $\sim 75 \%$ in urine, \\
& mostly unchanged & mostly metabolites & mostly metabolites \\
& drug & & \\
\hline
\end{tabular}

*Bioavailability data from animal studies.

$B I D=$ twice daily; $O D=$ once daily; $T_{\max }=$ time to maximum plasma concentration.

\section{Safety and Tolerability of Gliptins}

The inhibition of DPP-4 could potentially extend the circulating half-lives of many biologically active peptides with an Ala or Pro residue penultimate to the N-terminus, such as bradykinin, encephalins, neuropeptide $Y$, gastrin-releasing polypeptide, substance $P$ and monocyte chemoattractant protein-1. Thus, gliptins might conceivably affect vasoreactivity, monocyte behaviour, gastrointestinal motility and growth, as well as having an incretin-enhancing effect. ${ }^{78,81}$ However, there has been no evidence to date that gliptin therapy has any clinically significant or measurable effects on these physiological functions.

Since DPP-4 doubles as the CD-26 T-cell activating antigen, this has raised suspicion that gliptins could interfere with immune function. ${ }^{84}$ Gliptins are small molecules that are located deep within the structure of DPP-4, where they interrupt the peptidase activity. They thus leave the outer conformation of the protein intact and the immune function apparently unaffected.

In clinical trials gliptins have been well tolerated. Minor upper respiratory tract infections and urinary tract infections are common adverse events during long-term clinical trials. Despite this, their occurrence during gliptin therapy was not sufficiently raised during the pre-registration trials or during post-marketing surveillance to suggest any specific link to the therapy. Isolated severe hypersensitivity reactions to sitagliptin have been reported during the first three months of therapy. These include anaphylaxis, angioedema, exfoliate skin conditions and, very rarely, emerging signs of Stevens-Johnson syndrome. Monitoring for skin disorders such as rash, blistering and ulceration is recommended for all gliptins, but problems encountered during trials with monkeys have not materialised in humans. ${ }^{57-59}$

Caution is advised with advancing kidney or liver disease. Dose adjustments can enable sitagliptin and saxagliptin to be used with appropriate caution in severe renal disease, but there is no experience of their use in severe liver disease. Rare reports of raised alanine transaminase levels with vildagliptin have prompted caution in individuals with reduced liver function. ${ }^{85}$ The three gliptins currently available do not appear to significantly inhibit or induce the main P450 isoforms, but concomitant medications that inhibit P450 CYP3A4/5 (e.g. ketoconazole) may increase saxagliptin concentrations. Lack of experience with gliptins in patients with 
Table 2: Randomised Controlled Clinical Trials with Sitagliptin (Januvia) in Type 2 Diabetes

\begin{tabular}{|c|c|c|c|c|c|c|c|}
\hline Author & $\begin{array}{l}\text { Study } \\
\text { Design }\end{array}$ & $\begin{array}{l}\text { Duration } \\
\text { (weeks) }\end{array}$ & $\begin{array}{l}\text { Number of } \\
\text { Patients }\end{array}$ & $\begin{array}{l}\text { Dose } \\
\text { (mg/day) }\end{array}$ & $\begin{array}{l}\text { Other Antidiabetic } \\
\text { Treatment }\end{array}$ & $\begin{array}{l}\text { Mean } \\
\text { Baseline } \\
\mathrm{HbA}_{1 \mathrm{c}}(\%)\end{array}$ & $\begin{array}{l}\text { Placebo- } \\
\text { subtracted } \\
\text { Decrease in } \\
\mathrm{HbA}_{1 \mathrm{c}}(\%)\end{array}$ \\
\hline Aschner et al., & RDBPC & 24 & 741 & 100 & Diet only & 8.0 & $\downarrow 0.79$ \\
\hline $2006^{59}$ & & & & 200 & Diet only & 8.0 & $\downarrow 0.94$ \\
\hline $\begin{array}{l}\text { Charbonnel et al., } \\
2006^{60}\end{array}$ & RDBPC & 24 & 701 & 100 & Diet + metformin & 7.96 & $\downarrow 0.65$ \\
\hline $\begin{array}{l}\text { Rosenstock et al., } \\
2006^{61}\end{array}$ & RDBPC & 24 & 353 & 100 & Diet + pioglitazone & 8.05 & $\downarrow 0.70$ \\
\hline $\begin{array}{l}\text { Goldstein et al., } \\
2007^{62}\end{array}$ & RDBPC & 24 & $340^{*}$ & 100 & Diet only & 8.8 & $\downarrow 0.83$ \\
\hline $\begin{array}{l}\text { Nauck et al., } \\
2007^{63}\end{array}$ & RDBAC & 52 & 1,172 & 100 & Diet + metformin & 7.5 & $\downarrow 0.67$ \\
\hline $\begin{array}{l}\text { Hermansen et al., } \\
2007^{64}\end{array}$ & RDBPC & 24 & 441 & 100 & $\begin{array}{l}\text { Diet + glimepiride } \\
\text { Diet + glimepiride + metformin }\end{array}$ & 8.34 & $\begin{array}{l}\downarrow 0.57 \\
\downarrow 0.89\end{array}$ \\
\hline
\end{tabular}

*Number is the diet + placebo and the diet + sitagliptin arms only.

$H D A 1 C=$ glycated haemoglobin; RDBAC = randomised double-blind active comparator; RDBPC = randomised double-blind placebo controlled.

Table 3: Randomised Controlled Clinical Trials with Vildagliptin (Galvus) in Type 2 Diabetes

\begin{tabular}{|c|c|c|c|c|c|c|c|}
\hline Author & $\begin{array}{l}\text { Study } \\
\text { Design }\end{array}$ & $\begin{array}{l}\text { Duration } \\
\text { (weeks) }\end{array}$ & $\begin{array}{l}\text { Number of } \\
\text { Patients }\end{array}$ & $\begin{array}{l}\text { Dose } \\
\text { (mg/day) }\end{array}$ & $\begin{array}{l}\text { Other Antidiabetic } \\
\text { Treatment }\end{array}$ & $\begin{array}{l}\text { Mean } \\
\text { Baseline } \\
\mathrm{HbA}_{1 \mathrm{c}}(\%)\end{array}$ & $\begin{array}{l}\text { Placebo- } \\
\text { subtracted } \\
\text { Decrease in } \\
\mathrm{HbA}_{1 \mathrm{c}}(\%)\end{array}$ \\
\hline Ahren et al., 2004 ${ }^{65}$ & RDBPC & 52 & 107 & 100 & Diet + metformin & 7.7 & $\downarrow 1.1$ \\
\hline \multirow[t]{2}{*}{ Garber et al., 200766 } & RDBPC & 24 & 463 & 50 & Diet + pioglitazone & $8.7^{*}$ & $\downarrow 0.8$ \\
\hline & & & & 100 & Diet + pioglitazone & $8.7^{*}$ & $\downarrow 1.0$ \\
\hline Rosenstock et al., $2007^{67}$ & RDBAC & 24 & 519 & 100 & Diet only & 8.7 & $\downarrow 1.1$ \\
\hline Schweizer et al., $2007^{68}$ & RDBAC & 52 & 780 & 100 & Diet + metformin & 8.7 & $\downarrow 1.0^{\dagger}$ \\
\hline \multirow[t]{2}{*}{ Bosi et al., $2007^{69}$} & RDBPC & 24 & 544 & 50 & Diet + metformin & 8.4 & $\downarrow 0.7$ \\
\hline & & & & 100 & Diet + metformin & & $\downarrow 1.1$ \\
\hline
\end{tabular}

${ }^{*}$ Approximate $\mathrm{HbA1c}$ value estimated from illustration. ${ }^{\dagger}$ Decrease in $\mathrm{HbA1c}$ was $1.0 \%$ diet + vildagliptin versus $1.4 \%$ for diet + metformin .

$H D A 1 C=$ glycated haemoglobin; RDBAC = randomised double-blind active comparator; RDBPC = randomised double-blind placebo-controlled .

Table 4: Randomised Controlled Clinical Trials with Saxagliptin (Onglyza) in Type 2 Diabetes

\begin{tabular}{|c|c|c|c|c|c|c|c|}
\hline Author & $\begin{array}{l}\text { Study } \\
\text { Design }\end{array}$ & $\begin{array}{l}\text { Duration } \\
\text { (weeks) }\end{array}$ & $\begin{array}{l}\text { Number of } \\
\text { Patients }\end{array}$ & $\begin{array}{l}\text { Dose } \\
\text { (mg/day) }\end{array}$ & $\begin{array}{l}\text { Other Antidiabetic } \\
\text { Treatment }\end{array}$ & $\begin{array}{l}\text { Mean } \\
\text { Baseline } \\
\mathrm{HbA}_{1 \mathrm{c}}(\%)\end{array}$ & $\begin{array}{l}\text { Placebo- } \\
\text { subtracted } \\
\text { Decrease in } \\
\mathrm{HbA}_{1 \mathrm{c}}(\%)\end{array}$ \\
\hline $\begin{array}{l}\text { Rosenstock et al., } \\
2008^{70}\end{array}$ & RDBPC & 12 & 338 & $\begin{array}{l}2.5,5 \\
10,20,40\end{array}$ & Diet only & 7.9 & $\downarrow 0.45-0.63$ \\
\hline $\begin{array}{l}\text { DeFronzo et al., } \\
2009^{71}\end{array}$ & RDBPC & 24 & 743 & $2.5,5,10$ & Diet + metformin & 8.0 & $\downarrow 0.46-0.56$ \\
\hline $\begin{array}{l}\text { Chen et al., } \\
2008^{72}\end{array}$ & RDBAC & 24 & 1,306 & 5,10 & Diet + metformin & 9.5 & $\downarrow 0.50-0.54$ \\
\hline $\begin{array}{l}\text { Ravichandran et al., } \\
2008^{73}\end{array}$ & RDBAC & 24 & 768 & $2.5,5$ & Diet + glyburide & 8.4 & $\downarrow 0.54-0.64$ \\
\hline $\begin{array}{l}\text { Allen et al., } \\
2008^{74}\end{array}$ & RDBPC & 24 & 565 & $2.5,5$ & Diet + thiazolidinedione* & 8.3 & $\downarrow 0.36-0.64$ \\
\hline
\end{tabular}

* The thiazolidinedione was either pioglitazone or rosiglitazone.

$H D A 1 C=$ glycated haemoglobin; RDBAC = randomised double-blind active comparator; RDBPC = randomised double-blind placebo-controlled.

heart failure should be borne in mind. High dosages of gliptins have been associated with some adverse effects during pregnancy in animals, hence gliptins are not recommended in pregnancy and lactation. ${ }^{57-59}$ Although there have been reports of pancreatitis among patients taking gliptins, the incidence appears to be similar to that seen in the background population with type 2 diabetes: the occurrence of pancreatitis in type 2 diabetes is about 2.8 times higher than in the non-diabetic population. ${ }^{86}$

\section{Diverging Actions of the Incretins - Future Prospects}

It is widely held that the primary physiological role of incretins is to modulate plasma glucose. However, several independent lines of inquiry indicate that incretins have important functions relevant to pathophysiologies other than diabetes. There is a growing body of evidence indicating that incretin-related peptides have cardioprotective and neuroprotective actions that may combat other human 
diseases. At this stage it is too early to tell whether DPP-4 inhibitors could play a role in these actions. Their use will need to be reviewed periodically as and when new evidence comes to light.

\section{Cardioprotective Effects}

Patients with diabetes are characterised by an increased risk of developing both microvascular complications (e.g. retinopathy, nephropathy and neuropathy) and atherosclerotic macrovascular disease, potentially leading to the development of peripheral vascular disease, stroke and heart failure. ${ }^{87}$ In the UK, cardiovascular disease (CVD) is the leading cause of mortality and is linked to premature death in up to $40 \%$ of the population. ${ }^{87}$ Patients with diabetes are characterised by significantly elevated CVD risk compared with normoglycaemic individuals. ${ }^{88,89}$ The Framingham Heart Study determined that heart failure was twice as common in men with diabetes and five times as common in women with diabetes who were 45-74 years of age compared with the normal population and that this association was even stronger in younger patients. ${ }^{90}$

Recent evidence suggests that in addition to its established glucoselowering actions, GLP-1 may also exert several beneficial actions on the cardiovascular system, including improved left ventricular function and improved recovery after myocardial ischaemia. This introduces new therapeutic possibilities for the use of GLP-1 compounds in the treatment of CVD in both normal patients and those with diabetes. Recent evidence supports the existence of GLP-1 signalling pathways independent of the classic GLP-1R. The existence of multiple GLP-1RS within the cardiovascular system has not been ruled out. Several studies have suggested that the metabolically inactive form of GLP-1 (GLP-1(9-36) amide) may play a significant cardiovascular role (91,92 $^{9 n d}$ this has potential implications for DPP-4 inhibitor therapies.

The emerging cardiovascular actions of GLP-1 and the potential for GLP-1 as a treatment for CVD in both diabetic and non-diabetic patients has recently been reviewed in depth. ${ }^{93}$

\section{Neuroprotective Effects}

The central effects of GLP-1 to inhibit feeding are widely appreciated. They appear to be mediated by GLP-1 receptors located in the arcuate nucleus and other hypothalamic regions. ${ }^{5,94}$ Indeed, GLP-1 synthesised in the brain may activate these receptors as well as acting peripherally. GLP-1 triggers satiety pathways by gaining direct access through the blood-brain barrier in addition to activating sensory vagal afferent nerve fibres and other networks comprising the gut-brain axis. ${ }^{95}$ Stable GLP-1 receptor mimetics promote clinically significant bodyweight loss, whereas DPP-4 inhibitors are weight-neutral and generally lack effects on gastric emptying, presumably due to much lower concentrations of endogenous GLP-1 being achieved following therapy. GIP also lacks effects on feeding, but it is increasingly clear that, like GLP-1, many brain regions synthesise GIP and are endowed with functional GIP receptors. ${ }^{.6}$

Such observations fit well with growing evidence in preclinical studies that both GLP-1 and GIP increase cognition and exert potentially important central neuroprotective actions. ${ }^{5}$ Thus, DPP-4-resistant analogues of GLP-1 and GIP have recently been shown to improve hippocampal neurotransmitter release and synaptic plasticity, also protecting synapses from the detrimental neurodegenerative effects of beta-amyloid fragments. ${ }^{97,98}$ These observations suggest a possible therapeutic benefit of incretin hormones in Alzheimer's and other diseases associated with impaired cognitive function. ${ }^{99}$ Indeed GLP-1 receptor knockout mice demonstrate impaired synaptic plasticity and memory formation. ${ }^{100}$

Whether similar benefits might follow from the clinical use of DPP-4 inhibitors remains to be explored. Direct central effects can be discounted because DPP-4 inhibitors are generally designed not to cross the blood-brain barrier and the central nervous system contains very low levels of DPP-4 anyway. However, recent studies report a beneficial effect of sitagliptin on cognition and amyloid deposition in Alzheimer's prone mice. ${ }^{101,102}$

Neuroprotective effects of increased circulating incretin levels passing into the brain and/or by activation of peripheral sensory neural pathways are worthy of consideration, especially given their increasing recognition in glucoregulatory incretin effects. ${ }^{95,103}$

\section{Conclusion}

From their inception around a decade ago, gliptin drug therapies for type 2 diabetes have rapidly gone from concept to pre-clinical development to clinical adoption. Factors contributing to this are:

- the characterisation of the inactivation of GLP-1 and GIP by DPP-4;

- the parallel development of incretin analogues and mimetics; and

- the proven efficacy and suitability of gliptins for oral administration.

Currently, diabetologists have a selection of three approved gliptin therapies for managing hyperglycaemia, with further additions likely. Gliptins are suitable for mono- and combination therapy. They add to the growing array of antidiabetic drugs now available.

Gliptins are efficacious in lowering $\mathrm{HbA}_{1 \mathrm{c}}$ and so far are generally well tolerated, exhibiting few adverse effects and minimal risk of hypoglycaemia. The widespread use of gliptins will improve clinical knowledge and determine the long-term future of this new drug class in the management of type 2 diabetes.

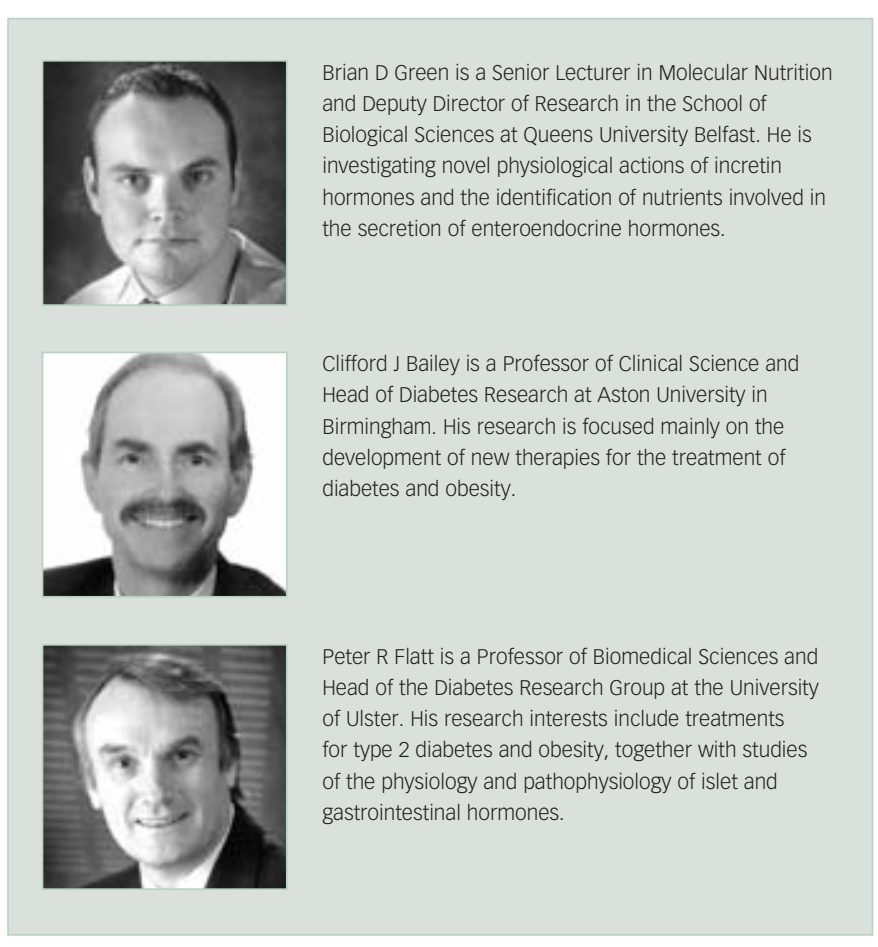


1. Moore B, Edia ES, Abram JH, On the treatment of diabetes mellitus by an extract of duodenal mucous membrane, Biochem J, 1906;1:28-38.

2. La Barre J, Sur les possibilités d'un traitement du diabe 'te par l'incrétine, Bull Acad R Med Belg, 1932;12:620-34.

3. Creuzfeldt $W$, The incretin concept today, Diabetologia, 1979;16:75-85.

4. Lund PK, Goodman RH, Dee PC, et al., Pancreatic preproglucagon cDNA contains two glucagon-related coding sequences arranged in tandem, Proc Natl Acad SCi U S A, 1982;79:345-9.

5. Baggio LL, Drucker DJ, Biology of incretins: GLP-1 and GIP, Gastroenterology, 2007;132:2131-57.

6. Green BD, Gault VA, O'Harte FP, et al., Structurally modified analogues of glucagon-like peptide-1 (GLP-1) and glucose-dependent insulinotropic polypeptide (GIP) as future antidiabetic agents, Curr Pharm Des, 2004:10:3651-62.

7. Kosaka T, Lim RKS, Demonstration of the humoral agent in fat inhibition of gastric acid secretion, Proc Soc Exp Biol Med, 1930;27:870-91.

8. Brown JC, Pederson RA, Jorpes E, et al., Preparation of highly active enterogastrone, Can J Physiol Pharm, 1969;47:113-4.

9. Brown JC, Mutt V, Pederson RA, Further purification of a polypeptide demonstrating enterogastrone activity, J Physiol, 1970;209:57-64.

10. Dupre J, Ross SA, Watson D, et al., Stimulation of insulin secretion by gastric inhibitory polypeptide in man, I Clin Endocrinol Metab, 1973;37:826-8

11. Brown JC, Pederson RA, The insulinotropic action of gastric inhibitory polypeptide in the perfused isolated rat pancreas, Endocrinology, 1976;99:780-5.

12. Pedersen RA. In: Walsh JH, Dockray GJ (eds), Gastric inhibitory polypeptide, Gut Peptides: Biochemistry an Physiology, New York: Raven Press, 1994;217-59.

13. Fehmann $\mathrm{HC}$, Habener JF, Insulinotropic hormone glucagon-like peptide-I(7-37) stimulation of proinsulin gen expression and proinsulin biosynthesis in insulinoma beta TC-1 cells, Endocrinology, 1992;130:159-66.

14. Fehmann $\mathrm{HC}$, Goke R, Characterization of $\mathrm{GIP}(1-30)$ and GIP(1-42) as stimulators of proinsulin gene transcription, Peptides, 1995; 16:1149-52.

15. Maida A, Hansotia T, Longuet C, et al., Differential importance of GIP vS GLP-1 receptor signaling for beta cell survival in mice, Gastroenterology, 2009;137(6): 2146-57.

16. Trümper $\mathrm{A}$, Trümper $\mathrm{K}$, Hörsch $\mathrm{D}$, Mechanisms of mitogenic and anti-apoptotic signaling by glucosedependent insulinotropic polypeptide in beta(INS-1)-cells, J Endocrinol, 2002;174:233-45.

17. Vilsbøll T, The effects of glucagon-like peptide-1 on the beta cell, Diabetes Obes Metab, 2009:11(Suppl. 3):11-18.

18. Eckel RH, Fujimoto WY, Brunzell JD, Gastric inhibitory polypeptide enhanced lipoprotein lipase activity in cultured preadipocytes, Diabetes, 1979; 28:1141-2.

19. Oben J, Morgan LM, Fletcher J, et al., Effect of the entero-pancreatic hormones, gastric inhibitory polypeptide and glucagon-like polypeptide-1(7-36) amide, on fatty acid synthesis in explants of rat adipose tissue, J Endocrinol, 1991;130:267-72.

20. Valverde I, Villanueva-Peñacarrillo ML, In vitro insulinomimetic [corrected] effects of GLP-1 in liver muscle and fat, Acta Physiol Scand, 1996:157:359-60.

21. Abbott CA, Gorrell, MD, The family of CD26/DPIV and related ectopeptidases in ectopeptidases: CD13/ aminopeptidase $\mathrm{N}$ and $\mathrm{CD} 26$ /Dipeptidyl peptidase IV. In: Langer J, Ansorge S (eds), Medicine and Biology, New York: Kluwer/Plenum, 2002:171-91.

22. Drucker DJ, Therapeutic potential of dipeptidyl peptidase IV inhibitors for the treatment of type 2 diabetes, Expert Opin Investig Drugs, 2003:12:87-100

23. Green BD, Flatt PR, Bailey CJ, Inhibition of dipeptidy peptidase IV activity as a therapy of type 2 diabetes, Expert Opin Emerg Drugs, 2006;11(3):525-39.

24. Mentlein R, Gallwitz B, Schmidt WE, Dipeptidyl-peptidase IV hydrolyses gastric inhibitory polypeptide, glucagon-like peptide-1(7-36)amide, peptide histidine methionine and is responsible for their degradation in human serum, Eur J Biochem, 1993;214:829-35.
25. Kieffer TJ, McIntosh $\mathrm{CH}$, Pederson RA, Degradation of glucose-dependent insulinotropic polypeptide and truncated glucagon-like peptide 1 in vitro and in vivo by dipeptidyl peptidase IV, Endocrinology, 1995;136,3585-96.

26. Deacon $\mathrm{CF}$, Johnsen $\mathrm{AH}$, Holst JJ, Degradation of glucagon-like peptide-1 by the human plasma in vitro yields an $\mathrm{N}$-terminally truncated peptide that is a majo endogenous metabolite in vivo, J Clin Endocrinol Metab, 1995;80:952-7.

27. Pridal L, Deacon CF, Kirk O, et al., Glucagon-like peptide$1(7-37)$ has a larger volume of distribution than glucagon-like peptide-17-36)amide in dogs and is degraded more quickly in vitro by dog plasma, Eur J Drug Metab Pharmacokinet, 1996;21:51-9.

28. Schmidt WE, Siegel EG, Kummel H, et al., Commercially available preparations of porcine glucose-dependent insulinotropic polypeptide (GIP) contain a biologically nactive GIP-fragment and cholecystokinin-33/-39. Endocrinology, 1987;120:835-7

29. Knudsen LB, Pridal L, Glucagon-like peptide-1-(9-36) amide is a major metabolite of glucagon-like peptide-1 (7-36) amide after in vivo administration to dogs, and it acts as an antagonist on the pancreatic receptor. Eur J Pharmacol, 1996;318:429-35.

30. Green BD, Mooney MH, Gault VA, et al., Lys9 for Glu9 substitution in glucagon-like peptide-1(7-36)amide confers dipeptidyl peptidase IV resistance with cellular and metabolic actions similar to those of established antagonists glucagon-like peptide-1(9-36)amide and exendin (9-39), Metabolism, 2004;53:252-9.

31. Wettergren A, Wøjdemann M, Holst JJ, The inhibitory effect of glucagon-like peptide-1 (7-36)amide on antra motility is antagonized by its $\mathrm{N}$-terminally truncated primary metabolite GLP-1 (9-36)amide, Peptides, 1998;19:877-82.

32. Deacon CF, Plamboeck A, Moller S, et al., GLP-1-(9-36) amide reduces blood glucose in anesthetized pigs by a mechanism that does not involve insulin secretion Am J Physiol Endocrinol Metab, 2002;282(4):E873-9.

33. Deacon CF, Plamboeck A, Rosenkilde MM, et al. GIP-(3-42) does not antagonize insulinotropic effects of GIP at physiological concentrations, Am J Physiol Endocrinol Metab, 2006;291:E468-75.

34. Gault VA, Parker JC, Harriott P, et al., Evidence that the major degradation product of glucose-dependent insulinotropic polypeptide, GIP(3-42), is a GIP receptor antagonist in vivo, J Endocrinol, 2002;175:525-33.

35. Hinke SA, Gelling RW, Pederson RA, et al., Dipeptidyl peptidase IV-resistant [D-Ala(2)]glucose-dependent insulinotropic polypeptide (GIP) improves glucose tolerance in normal and obese diabetic rats, Diabetes, 2002;51:652-61

36. Parker JC, Lavery KS, Irwin N, et al., Effects of subchronic exposure to naturally occurring $\mathrm{N}$-terminally truncated metabolites of glucose-dependent insulinotrophic polypeptide (GIP) and glucagon-like peptide-1 (GLP-1), GIP(3-42) and GLP-1(9-36)amide, on insulin secretion and glucose homeostasis in ob/ob mice, J Endocrinol, 2006;191:93-100.

37. Irwin N, Flatt, PR, Evidence for beneficial effects of compromised gastric inhibitory polypeptide action in obesity-related diabetes and possible therapeutic implications, Diabetologia, 2009;52:1724-31.

38. Green BD, Liu HK, McCluskey JT, et al., Function of a long-term, GLP-1-treated, insulin-secreting cell line is improved by preventing DPP IV-mediated degradation of GLP-1, Diabetes Obes Metab, 2005;7:563-9.

39. Rahfeld J, Schierhorn M, Hartrodt B, et al., Are diprotin A (lle-Pro-lle) and diprotin B (Val-Pro-Leu) inhibitors or substrates of dipeptidyl peptidase IV?, Biochim Biophys Acta, 1991;1076:314-6.

40. Thoma R, Löffler B, Stihle M, et al., Structural basis of proline-specific exopeptidase activity as observed in human dipeptidyl peptidase-IV, Structure, 2003;11:947-59.

41. Marguet D, Baggio L, Kobayashi T, et al., Enhanced insulin secretion and improved glucose tolerance in mice lacking CD26, Proc Natl Acad Sci U S A, 2000;97:6874-9.

42. Nagakura T, Yasuda $N$, Yamazaki K, et al., Enteroinsular axis of $\mathrm{db} / \mathrm{db}$ mice and efficacy of dipeptidyl peptidase IV inhibition, Metabolism, 2003;52:81-6.
43. Conarello SL, Li Z, Ronan J, et al., Mice lacking dipeptidy peptidase IV are protected against obesity and insulin resistance, Proc Natl Acad Sci U S A, 2003;100:6825-30.

44. Yasuda N, Nagakura T, Yamazaki K, et al., Improvement of high fat-diet-induced insulin resistance in dipeptidyl peptidase IV-deficient Fischer rats, Life Sci, 2002;71:227-38.

45. Pederson RA, White HA, Schlenzig D, et al., Improved glucose tolerance in Zucker fatty rats by oral administration of the dipeptidyl peptidase IV inhibitor isoleucine thiazolidide, Diabetes, 1998:47:1253-8.

46. Pospisilik JA, Stafford SG, Demuth HU, et al., Long-term treatment with the dipeptidyl peptidase IV inhibitor P32/98 causes sustained improvements in glucose tolerance, insulin sensitivity, hyperinsulinemia, and betacell glucose responsiveness in VDF (fa/fa) Zucker rats, Diabetes, 2002;51:943-50

47. Pospisilik JA, Stafford SG, Demuth HU, et al., Long-term treatment with dipeptidyl peptidase IV inhibitor improves hepatic and peripheral insulin sensitivity in the VDF Zucker rat: a euglycemic-hyperinsulinemic clamp study, Diabetes, 2002;51:2677-83.

48. Burkey BF, Li X, Bolognese L, et al., Acute and chronic effects of the incretin enhancer vildagliptin in insulinresistant rats, J Pharmacol Exp Ther, 2005;315:688-95.

49. Balkan B, Kwasnik L, Miserendino R, et al., Inhibition of dipeptidyl peptidase IV with NVP-DPP728 increases plasma GLP-1 (7-36 amide) concentrations and improves oral glucose tolerance in obese Zucker rats, Diabetologia, 1999;42:1324-31.

50. Ahrén $\mathrm{B}$, Holst JJ, Mårtensson $\mathrm{H}$, et al., Improved glucose tolerance and insulin secretion by inhibition of dipeptidyl peptidase IV in mice, Eur J Pharmacol, 2000;404:239-45.

51. Roy S, Khanna V, Mittra S, et al., Combination of dipeptidyl peptidase IV inhibitor and low dose thiazolidinedione: Preclinical efficacy and safety in $\mathrm{db} / \mathrm{db}$ mice, Life Sci, 2007;81:72-9.

52. Yamazaki K, Inoue T, Yasuda N, et al., Comparison of efficacies of a dipeptidyl peptidase IV inhibitor and alphaglucosidase inhibitors in oral carbohydrate and meal tolerance tests and the effects of their combination in mice, J Pharmacol Sci, 2007;104:29-38.

53. Biftu T, Feng D, Qian $X$, et al., (3R)-4-[(3R)-3-Amino-4(2,4,5-trifluorophenyl)butanoyl]-3-(2,2,2-trifluoroethyl)-1,4diazepan-2-one, a selective dipeptidyl peptidase IV inhibitor for the treatment of type 2 diabetes, Bioorg Med Chem Lett, 2007;17:49-52

54. Thomas L, Eckhardt $\mathrm{M}$, Langkopf $\mathrm{E}$, et al., (R)-8-(3-aminopiperidin-1-yl)-7-but-2-ynyl-3-methyl-1-(4-methylquinazolin-2-ylmethyl)-3,7-dihydro-purine-2,6-dione (BI 1356), a novel xanthine-based dipeptidyl peptidase 4 inhibitor, has a superior potency and longer duration of action compared with other dipeptidyl peptidase-4 inhibitors, J Pharmacol Exp Ther, 2008:325:175-82.

55. Eckhardt M, Langkopf E, Mark M, et al., 8-(3-(R)aminopiperidin-1-yl)-7-but-2-ynyl-3-methyl-1-(4-methylquinazolin-2-ylmethyl)-3,7-dihydropurine-2,6-dione (BI 1356), a highly potent, selective, long-acting, and orally bioavailable DPP-4 inhibitor for the treatment of type 2 diabetes, J Med Chem, 2007;50:6450-3

56. Summary of Product Characteristics, Sitagliptin, Merck Sharp \& Dohme Ltd, Hoddesdon, UK, June 2009 (available at: www.januvia.com, accessed 17 June 2010)

57. Summary of Product Characteristics, Vildagliptin, Novartis Europharm Ltd, Horsham, UK, January 2008. Available at: www.medicines.org.uk/EMC/medicine /20734/SPC/Galvus+50+mg+Tablets/

58. Summary of Product Characteristics, Saxagliptin, BristolMyers Squibb/AstraZeneca, Uxbridge, UK, October 2009 Available at: www.medicines.org.uk/emc/ingredient/ 2424/saxagliptin+hydrochloride/ (accessed 17 June 2010)

59. Aschner P, Kipnes M, Lunceford J, et al., Effect of the dipeptidyl peptidase-4 sitagliptin as monotherapy on glycemic control in patients with type 2 diabetes, Diabetes Care, 2006;29:2632-7.

60. Charbonnel B, Karisik A, Liu J, et al., Efficacy and safety of the dipeptidyl peptidase-4 inhibitor sitagliptin added to ongoing metformin therapy in patients with type 2 diabetes inadequately controlled with metformin alone, Diabetes Care, 2006;29:2638-43

61. Rosenstock J, Brazg R, Andryuk P, et al., Efficacy and 
safety of the dipeptidyl peptidase-4 inhibitor sitagliptin added to ongoing pioglitazone therapy in patients with type 2 diabetes: a 24-week, multicenter, randomized, double-blind, placebo-controlled, parallel-group study, Clin Therapeutics, 2006;28:1556-68.

62. Goldstein BJ, Feinglos MN, Lunceford, et al., Effect of initial combination therapy with sitagliptin, a dipeptidyl peptidase-4 inhibitor, and metformin on glycemic control in patient with type 2 diabetes, Diabetes Care, 2007;30: 1979-87.

63. Nauck MA, Meininger G, Sheng D, et al., Efficacy and safety of the dipeptidyl peptidase- 4 inhibitor, sitagliptin, compared with the sulfonylurea, glipizide, in patients with type 2 diabetes inadequately controlled on metformin alone: a randomized, double-blind, noninferiority trial, Diabetes Obes Metab, 2007;9:194-205.

64. Hermansen K, Kipnes M, Luo E, et al., Efficacy and safety of the dipeptidyl peptidase-4 inhibitor, sitagliptin, in patients with type 2 diabetes mellitus inadequately controlled on glimepiride and metformin, Diabetes Obes Metab, 2007;9:733-45.

65. Ahrén B, Gomis R, Standl E, et al., Twelve and 52-week efficacy of the dipeptidyl peptidase IV inhibitor LAF237 in metformin treated patients with type 2 diabetes, Diabetes Care, 2004;27:2874-80.

66. Garber AJ, Schweizer A, Baron MA, et al., Vildagliptin in combination with pioglitazone improves glycaemic control in patients with type 2 diabetes failing thiazolidinedione monotherapy: a randomized placebocontrolled study, Diabetes Obes Metab, 2007;9:166-74.

67. Rosenstock J, Baron MA, Dejager S, et al., Comparison of vildagliptin and rosiglitazone monotherapy in patients with type 2 diabetes, Diabetes Care, 2007;30:217-23.

68. Schweizer A, Couturier A, Foley J, et al., Comparison between vildagliptin and metformin to sustain reductions in HbA1C over 1 year in drug-naive patients with type 2 diabetes, Diabetic Med, 2007;24:955-61.

69. Bosi E, Camisasca RP, Collober C, et al., Effect of vildagliptin on glucose control over 24 weeks in patients with type 2 diabetes inadequately controlled with metformin, Diabetes Care, 2007;30:890-5.

70. Rosenstock J, Sankoh S, List JF, Glucose-lowering activity of the dipeptidyl peptidase-4 inhibitor saxagliptin in drug naiive patients with type 2 diabetes, Diabetes Obes Metab, 2008;10:376-86

71. DeFronzo RA, Hissa MN, Garber AJ, et al., The efficacy and safety of saxagliptin when added to metformin therapy in patients with inadequately controlled type 2 diabetes on metformin alone, Diabetes Care, 2009:32:1649-55.

72. Chen R, Pfutzner A, Jadzinsky M, et al., Initial combination therapy with saxagliptin and metformin improves glycaemic control compared with either monotherapy alone in drug-naive patients with type 2 diabetes, Diabetologia, 2008;51(Suppl. 1):78.

73. Ravichandran S, Chacra AR, Tan GH, et al., Saxagliptin added to sufonylurea is safe and more efficacious than up-titrating a sulfonylurea in patients with type 2 diabetes, Diabetologia, 2008;51(Suppl. 1):858

74. Allen E, Hollander P, Li J, et al., Saxagliptin added to a thiazolidinedione improves glycaemic control in patients with inadequately controlled type 2 diabetes, Diabetologia, 2008;51(Suppl. 1):859.

75. Croxtall JD, Keam DSJ, Vildagliptin: a review of its use in the management of type 2 diabetes mellitus, Drugs, 2008;68:2387-409

76. Garber AJ, Foley JE, Banerji MA, Effects of vildagliptin on glucose control in patients with type 2 diabetes inadequately controlled with a sulfonylurea, Diabetes obes Metab, 2008; 10:1047-56.

77. Deacon CF, Holst JJ, Dipeptidyl peptidase-4 inhibition: advances in our understanding of diabetes management, Europ Endocrinol, 2008:4:47-9.

78. Ahrén B, Emerging dipeptidyl peptidase-4 inhibitors for the treatment of diabetes, Expert Opin Emerging Drugs, 2008;13:593-607.

79. Verspohl EJ, Novel therapeutics for type 2 diabetes: incretin hormone mimetics (glucagon-like peptide-1 receptor agonists) and dipeptidyl peptidase-4 inhibitors, Pharmacol Ther, 2009;124:113-38.

80. Matikainen N, Manttari S, Schweizer A, et al., Vildagliptin therapy reduces postprandial intestinal triglyceride-rich lipoprotein particles in patients with type 2 diabetes, Diabetologia, 2006;49:2049-57.

81. Green BD, Flatt PR, Bailey CJ, Inhibition of dipeptidyl peptidase IV activity as a therapy of type 2 diabetes, Expert Opin Emerging Drugs, 2006;11:525-39.

82. Rayasam GV, Tulasi VK, Davis JA, et al., Fatty acid receptors as new therapeutic targets for diabetes, Expert Opin Ther Targets, 2007;11:661-71.

83. Evans KA, Budzik BW, Ross SA, et al., Discovery of 3-Aryl-4-isoxazolecarboxamides as TGR5 Receptor Agonists, J Med Chem, 2009;52(24):7962-5.

84. Flatt PR, Bailey CJ, Green BD, Dipeptidyl peptidase IV (DPP IV) and related molecules in type 2 diabetes, Front Biosci, 2008;13:3648-60

85. Amori RE, Lau J, Pittas AG, Efficacy and safety of incretin therapy in type 2 diabetes: systematic review and metaanalysis, JAMA, 2007;298:194-206.

86. Noel RA, Braun DK, Patterson RE, et al., Increased risk of acute pancreatitis and biliary disease observed in patients with type 2 diabetes. A retrospective cohort study, Diabetes Care, 2009;32:834-8.

87. Clements Jr RS, Bell DS, Complications of diabetes. Prevalence, detection, current treatment, and prognosis, Am J Med, 1985;79:2-7.

88. Garcia MJ, MCNamara PM, Gordon T, et al., Morbidity and mortality in diabetics in the Framingham population.
Sixteen year follow-up study, Diabetes, 1974;23:105-11.

89. Scandinavian Simvastatin Survival Study Group, Randomised trial of cholesterol lowering in 4444 patients with coronary heart disease: the Scandinavian Simvastatin Survival Study (4S), Lancet, 1994;344: 1383-9.

90. Kannel WB, McGee DL, Diabetes and cardiovascular disease. The Framingham study, JAMA, 1979;241:2035-8

91. Ban K, Noyan-Ashraf MH, Hoefer J, et al., Cardioprotective and vasodilatory actions of glucagonlike peptide 1 receptor are mediated through both glucagon-like peptide 1 receptor-dependent and independent pathways, Circulation, 2008;117:2340-50.

92. Green $B D$, Hand KV, Dougan JE, et al., GLP-1 and related peptides cause concentration-dependent relaxation of rat aorta through a pathway involving KATP and CAMP, Arch Biochem Biophys, 2008;478:136-42.

93. Grieve DJ, Cassidy RS, Green BD, Emerging cardiovascular actions of the incretin hormone glucagonlike peptide-1: potential therapeutic benefits beyond glycaemic control?, Br J Pharmacol, 2009;157:1340-51.

94. Holst JJ, The physiology of glucagon-like peptide-1, Physiol Rev, 2007;87:1409-39.

95. Burcelin R, Serino M, Cabou C, A role for the gut-to-brain GLP-1-dependent axis in the control of metabolism, Curr Opin Pharmacol, 2009;9:744-52.

96. McIntosh CHS, Widenmaier S, Kim SJ, Glucosedependent insulinotropic polypeptide (gastric inhibitory polypeptide; GIP), Vit Horm, 2009;80:409-71.

97. Gault VA, Hölscher C, GLP-1 agonists facilitate hippocampal LTP and reverse the impairment of LTP induced by beta-amyloi, Eur J Phamacol, 2008;587:112-7.

98. Gault VA, Hölscher C, Protease resistant glucosedependent insulinotropic polypeptide agonists facilitate hippocampal LTP and reverse the impairment of LTPinduced by beta-amyloid, I Neurophysiol, 2008;99:1590-5.

99. Hölscher $\mathrm{C}$, Incretin analogues that have been developed to treat type 2 diabetes hold promise as a novel treatment strategy for Alzheimer's disease, Recent Pat CNS Drug Discov, 2010 Jun;5(2):109-17.

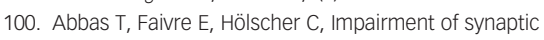
plasticity and memory formation in GLP-1 receptor KO mice: Interaction between type 2 diabetes and Alzheimer's disease, Behav Brain Res, 2009;205:265-71.

101. Larsen PJ, Holst JJ, Glucagon-related peptide 1 (GLP-1): hormone and neurotransmitter, Regul Pept, 2005;128: 97-107.

102. D'Amico M, Di Filippo C, Marfella R, et al., Long-term inhibition of dipeptidyl peptidase-4 in Alzheimer's prone mice, Exp Gerontol. 2010 Mar;45(3):202-7.

103. Williams DL, Minireview: Finding the sweet spot: Peripheral versus central glucagon-like peptide 1 action in feeding and glucose homeostasis, Endocrinology, 2009;150:2997-3001. 